\title{
An Efficient Carbon Coating Process Applied in Different Synthetic Routes of $\mathrm{LiFePO}_{4}$ Cathode Materials
}

\author{
Guan Wu, Tingting Jiang, Xiaohui Tian, Yanbin Zhu, Yingke Zhou* \\ The State Key Laboratory of Refractories and Metallurgy, Institute of Advanced Materials and \\ Nanotechnology, College of Materials and Metallurgy, Wuhan University of Science and Technology, \\ Wuhan 430081, China \\ *E-mail: Zhouyingke@wust.edu.cn
}

doi: $10.20964 / 2018.08 .07$

Received: 22 March 2018 / Accepted: 20 May 2018 / Published: 5 July 2018

\begin{abstract}
Four $\mathrm{LiFePO}_{4} / \mathrm{C}$ composites have been successfully synthesized via $\mathrm{Fe}_{2} \mathrm{O}_{3}$ route, $\mathrm{FeC}_{2} \mathrm{O}_{4}$ route, $\mathrm{FePO}_{4}$ route in solid-state method and $\mathrm{FeSO}_{4}$ route in hydrothermal method with an efficient carbon coating process which innovatively employed compound carbon sources that consisted of fructose and calcium lignosulfonate. Kilogram grade pilot samples have been prepared and $2000 \mathrm{mAh}$ pouch cells have been assembled and investigated. Due to the introduction of fructose and calcium lignosulfonate, the asprepared $\mathrm{LiFePO}_{4} / \mathrm{C}$ composites possess a layer of conductive carbon that contains calcium compound on the surface of $\mathrm{LiFePO}_{4}$ particles, which are supposed to improve the electronic conductivity and reduce the side reaction between $\mathrm{LiFePO}_{4}$ and electrolytes. All of the as-prepared $\mathrm{LiFePO}_{4} / \mathrm{C}$ composites show different characteristics in full cells, the capacity retention of $\mathrm{Fe}_{2} \mathrm{O}_{3}$ derived LFP-S1 was as high as $92.2 \%$ after 400 days storage, the capacity retention of $\mathrm{FeC}_{2} \mathrm{O}_{4}$ derived LFP-S2 at 5C rate was $93.0 \%$, the capacity retention of $\mathrm{FePO}_{4}$ derived LFP-S3 at $-20{ }^{\circ} \mathrm{C}$ was $66.7 \%$, the capacity retention of $\mathrm{FeSO}_{4}$ derived LFP-S4 was as high as $90.2 \%$ after 3000 cycles at $25^{\circ} \mathrm{C}$.
\end{abstract}

Keywords: $\mathrm{LiFePO}_{4}$; carbon coating; solid-state; Hydrothermal; Lithium-ion batteries

\section{FULL TEXT}

(C) 2018 The Authors. Published by ESG (www.electrochemsci.org). This article is an open access article distributed under the terms and conditions of the Creative Commons Attribution license (http://creativecommons.org/licenses/by/4.0/). 